\title{
Development Of Disaster Mitigation Curriculum To Improve Disaster Response Capabilities At The Elementary School In Indonesia
}

\author{
Wahyu Pratama Putra1, Dian Ahmad Sasmito,2, Rachima Dianovitasari Divian Kass ${ }^{3}$ \\ ${ }^{1,3}$ Educatinoal Technology, Universitas Negeri Malang \\ ${ }^{2}$ Geography Education, Universitas Negeri Malang \\ Email: dianahmadsasmito@gmail.com
}

\begin{abstract}
Disasters threaten the safety of vulnerable groups such the eldery, children and women. Based on the case of natural disasters that occurred in Indonesia, the need for a pragmatic strategy in forming the Indonesian people are aware of the dangers of natural disasters. One strategic step that taken is through the education sector. This research aims to create a disaster mitigation curriculum that has been formulated to produce disaster responsive learners. This research uses $\mathrm{R} \& \mathrm{D}$ (research and development method) by Borg and Gall (2003), in the stages of research and information, planning and initial product development. While for curriculum development used the Tyler model with the infusion method and block method. Data collection techniques used namely interviews, observation, and documentation. The findings of this research are based curriculum products to the stages of disaster mitigation include, 1) the concept of disaster mitigation curriculum, 2) The concept of the learning process (Intrakurikuler), 3) The concept of training process (Extracurricular, and 4) The concept of the assessment process (Evaluation). These results indicate curriculum products are made to increase disaster response capabilities of students through intracurricular and extracurricular activities as well as minimizing the impact of the disaster victims and improve disaster response capabilities for students in Indonesia.
\end{abstract}

Keywords: Curriculum, Disaster Mitigation, Tyler's Model.

\section{INTRODUCTION}

In terms of geology, Indonesia is a very interesting region. Indonesia has large continental shelf areas that have the most active plate movements and many mountain folds. According to BNPB (National Board for Disaster Management) in 2017 Indonesia is part of a meeting of three large tectonic plates namely the Indo-Australian Plate, the Eurasian Plate, and the Pacific Plate (BNPB.2016) .Moreover, Indonesia's position in Ring Of Fire has caused the region of Indonesia to have many active overthrust distributions. More than 200 active overthrust have been mapped by the government, but it is estimated that many other active overthrust have not yet been 
mapped at this time. It is was caused the region of Indonesia to frequently occurred natural disasters. Based on the perspective of Geography, Geology, Climatology and Demography, Indonesia is ranked 7 th from the list of countries most vulnerable to natural disaster risk (Rizaldy, D.2018).

The Indonesian region has 12 disaster threats grouped into Geological disasters (earthquakes, tsunamis, volcanoes, land movements and landslides), Hydrometeorological disasters (floods, flash floods, droughts, extreme weather, extreme tidal waves, forest and field fires), and Anthropogenic disasters (epidemics, diseases and technological failures (BNPB, 2014). According to BNPB (National Board for Disaster Management) in 2018, disaster risk index data there were 5092 disasters, 5084 victims, 11,090,861 people injured and displaced, see in figure 1. Data shows that disaster events have increased significantly in the past decade.

The Number Of Disaster Events In Indonesia 2018

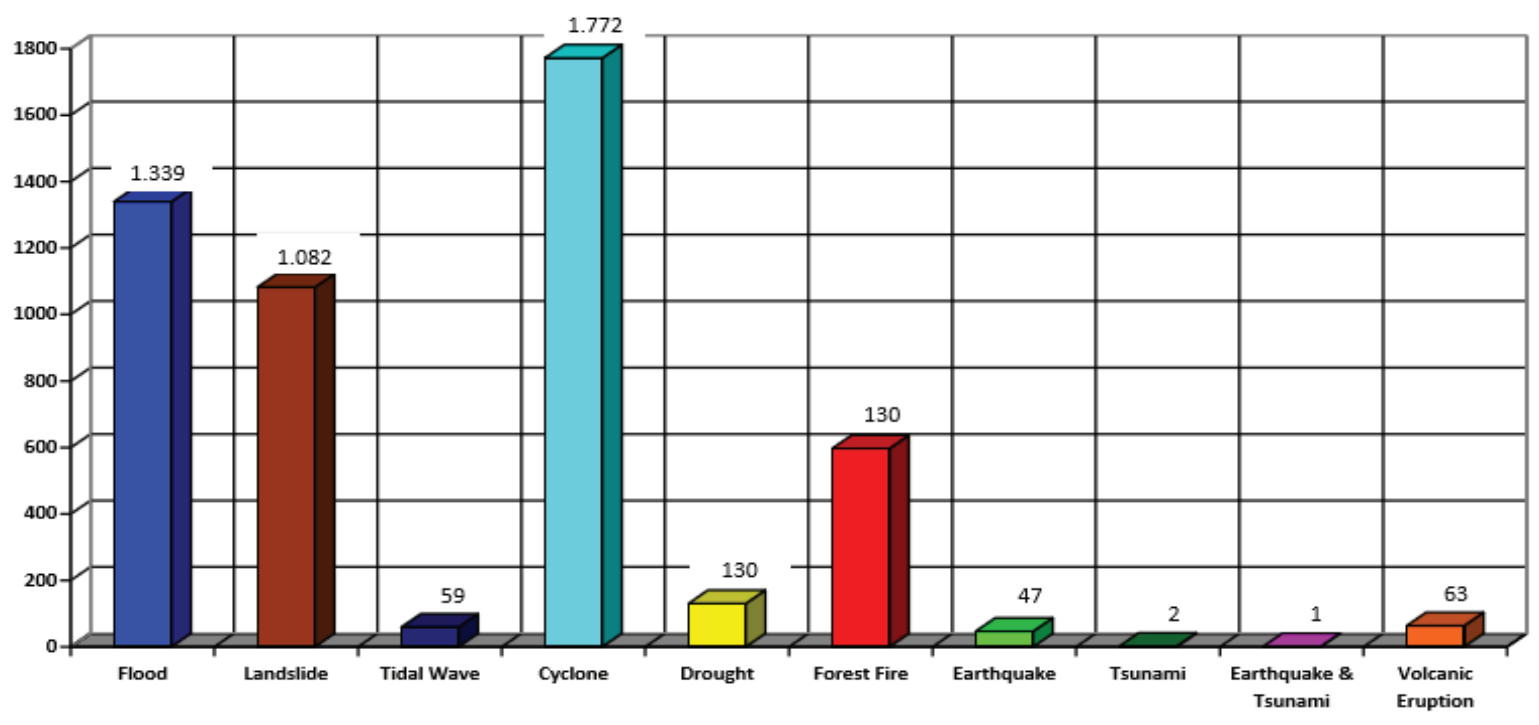

Figure 1. The Number Of Disaster Events In Indonesias On 2018 (BNPB, 2019)

Basically the disaster is five things, namely the causes of disasters and vulnerabilities (natural and human factors), the impact of disasters (environmental damage, victims and losses), the role of the government (disaster management policies), the role of the community (victims, causes factor or saviors), the influence and actions of stakeholders related to the threat of danger and disaster (K.R.C,et. al. 2013). The key to dealing with these problems is to give knowledge to the public about the importance of disaster mitigation

Disasters often threaten the safety of vulnerable groups such as the elderly, children and women. According to BNPB in 2017 there are approximately 
$70 \%$ or 250,000 of the 497,576 schools in Indonesia located in disaster-prone locations. From these data, it is known that children have the most vulnerability to disasters, because they have limited capacity and ability to overcome with disasters. Therefore, disaster education is an effective step that starts from school to give disaster mitigation knowledge to students (Jhonston, et.al. 1999)

The important role of knowledge about risk or hazard level as an effort to take preparations or action when a disaster occurs. School education about disasters is influential in developing knowledge and perceptions about earthquakes (disasters) research identified that disaster mitigation education in schools gives students with an understanding of pre-disaster preparation, during disasters, and postdisaster.

The efforts are made to create disaster mitigation programs or learning in schools by incorporating disaster mitigation into the curriculum. Definition of curriculum is a set of plans and arrangements about the purpose, content, and material and the methods used as guidelines for the implementation of learning activities to achieve certain educational objectives. (UU No. 20 Tahun 2003)

\section{METHOD}

This research used $\mathrm{R} \& \mathrm{D}$ (research and development) methods by Borg and Gall (2003), namely in the stages of research and information, planning and initial product development. This research inserted disaster mitigation into the curriculum, carried out with four processes to produce disaster mitigation curriculum products including: 1) Concept of disaster mitigation curriculum. 2) Learning Process (Intracuricular). 3) Training Process (Extracurricular. 4) Assessment Process (Evaluation).

Data collection techniques used are: 1) Interview, carried out to discuss about aspects of the disaster mitigation curriculum with teachers, principals, government officials, curriculum experts and disaster mitigation experts. 2) Observation, carried out to know the condition of the disaster impact and the role of education in an effort to overcome these problems). 3) Documentation, this type of data collection is used to obtain data or documents in the form and concept of the curriculum). While, the analysis technique used to answer the research problems and for the validity of the model developed is descriptive quality).

The method used to integrate disaster mitigation in the curriculum is the infusion method and block method. The infusion method is a method that incorporate a specific material in the curriculum by inserting it into related subjects (Apriani, 2012). The material that was incorporated in the learning process was themed "Natural Disasters" in Fourth-Graders of Elementary School. This method used the student center learning approach and the scientific learning model, with lecture, discussions, and demonstrations learning methods. there are steps to implement the infusion method in the curriculum, namely 1) select the topic, 2) Identify the curriculum subject areas, 3) Add the new objective education on the topic, 4) Describe new instructional techniques, 5) Identify new skills and skills that are needed, and 6) Describe any activities and topics, (Judy, A.B, et.al. 1993.) 
In this research the block method was inserted in the training activities guided by a special team and teacher. Block method is a way of inserting certain material into the curriculum by developing a separate subject specifically about the material (Apriani, 2012). The aim is to train students to be able to practice disaster mitigation efforts. The learning method used is demonstration and practice, while the media is adapted to disaster material that is practiced. The implementation of the block method is carried out by preparing syllabus which includes objectives, material, core competencies, basic competencies and RPP (the design of learning implementation) see in figure 2)

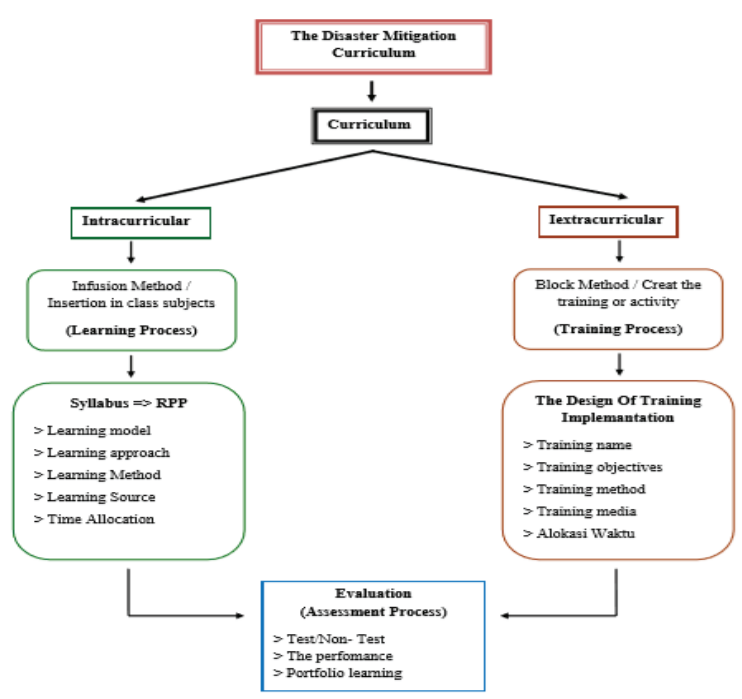

Figure 2. The Design of Integration of Disaster Mitigation Curriculum

\section{FINDINGS AND DISCUSSION}

This research produced a disaster mitigation curriculum at the elementary school. Curriculum products are made based on the 2013 curriculum guide with the Student Centered Learning. Disaster mitigation curriculum development based on a development model Tyler (expanded), which emphasizes the objectives with the product or outcomes approach. The stages of this model, consisting of: 1) Needed and current development analysis, 2) Identification of the tentative general objectives, 3) Selection by the philosophy of education and learning, 4) Formulation instructional objectives, 5) Selection of learning experience, 6) Organization of learning experience, 7) Direction of learning experience, and 8) Evaluation of learning experience (Okpokwasili, 2003). Stages in this model, according to curriculum development in 2013. Based on the model, the entire instructional design aimed to achieve objectives to be controlled by taking into account the learning experience that will be given to the learners. ( Howard, 2007).

\section{Disaster Mitigation Based Curriculum}

Disaster mitigation education can be included in the development of 2013 curriculum (K13) of Elementary Education as an effort to cultivate self-skills in dealing with natural disasters (UU. No. 20 Tahun 2003) . Preparation of Curriculum based on disaster mitigation begins with the preparation of curriculum objectives consisting of 1) National Education Objectives, 2) School or Regional Objectives and 3) Needs Analysis. Disaster mitigation education is loaded into needs analysis as a special needs to be achieved. These objectives are the basis for the preparation of SKL (Graduation Competency Standards). SKL are criteria regarding the qualifications of graduates' abilities which include the attitudes, knowledge, and skills expected to be 
achieved after completing a certain level of education (Peraturan KEMENDIKBUD No.20 Tahun 2016). SKL is a reference to curriculum development, content standards, process standards and assessment standards.

THE CONCEPT OF DISASTER MITIGATION CURRICULUM

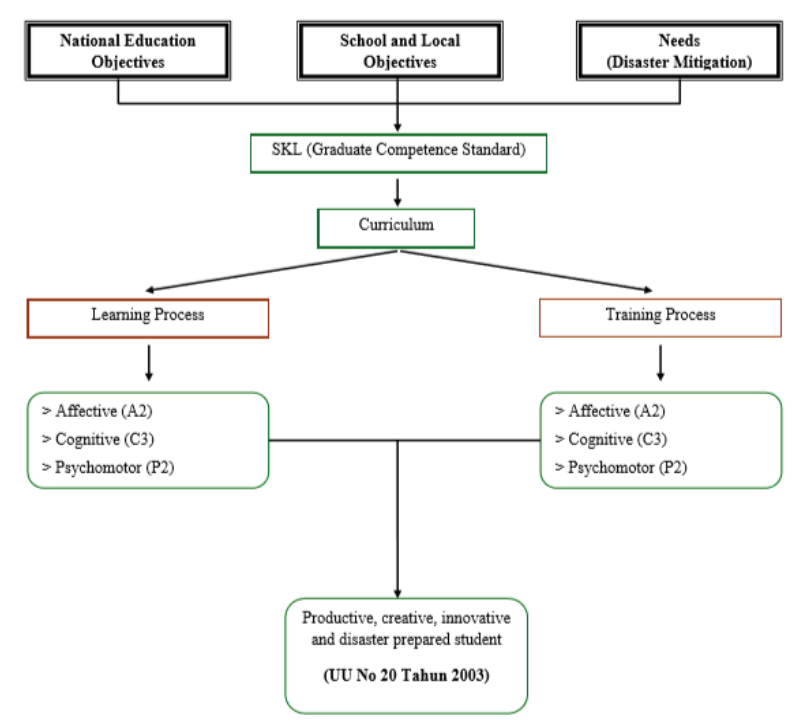

Figure 3. The Concept of Disaster Mitigation Based Curriculum.

Structure of the elementary school curriculum consists of 3 components: class subjects, local content subjects and self development. Disaster mitigation education is incorporated by the infusion method in Social Sciences subjects (Peraturan KEMENDIKBUD No.22 Tahun 2006). Whereas for self-development or extracurricular activities created using the block method is a disaster mitigation training program. Both of these connect and strengthen each other. The learning process emphasizes cognitive aspects or C3 (application) to instill understanding of disaster mitigation and practice it, while the training process emphasizes psychomotor aspects or P2 (manipulating) to encourage mitigation practices directly. Integrating both of them is more effective in forming productive, creative, innovative, affective students and having disaster mitigation skills (UU.No. 20 Tahun 2003), see in figure 3.

\section{The Design of Learning Processes (Intracurricular)}

The learning design of disaster mitigation curriculum begins with the preparation of Institutional Objectives contained in the SKL (Peraturan KEMENDIKBUD No.20 Tahun 2016) . The institutional objectives that have been prepared are then used as references as the preparation of disaster mitigation curriculam (Peraturan KEMENDIKBUD No.22 Tahun 2006) . The KI (Core Competence) and KD (Basic Competence) of the Disaster Mitigation Curriculum are arranged every level of education from a lower level to a higher level. In addition, $\mathrm{KI}$ and $\mathrm{KD}$ are arranged per subject based on the curriculum that has been prepared. the three steps of the preparation are interrelated with each other and mutually reinforcing and are the basis for the preparation of KI and KD. The syllabus that has been made becomes the basis for the formation of the RPP which in this case contains the process of learning in the classroom. The RPP contains approaches, modules, methods, media, material, learning resources, and time allocation.

Curriculum Disaster Mitigation used the Student Centered Learning approach so that all activities that occur are student-centered. The Learning method applied is the form of question and answer, practice, 
and demonstration. The learning media used in the form of real media objects, mock, digital, and the material in accordance with the curriculum that has been designed. Learning resources used in the learning process is the book which the preparation is specifically carried out by a team of curriculum developers with attention to critical aspects of the curriculum for disaster mitigation and another guide book. In this research, disaster mitigation education was inserted in three steps, namely the preparation of institutional objectives, curriculum, and syllabus, see in figure 4.

\section{THE CONCEPT OF LEARNING PROCESS}

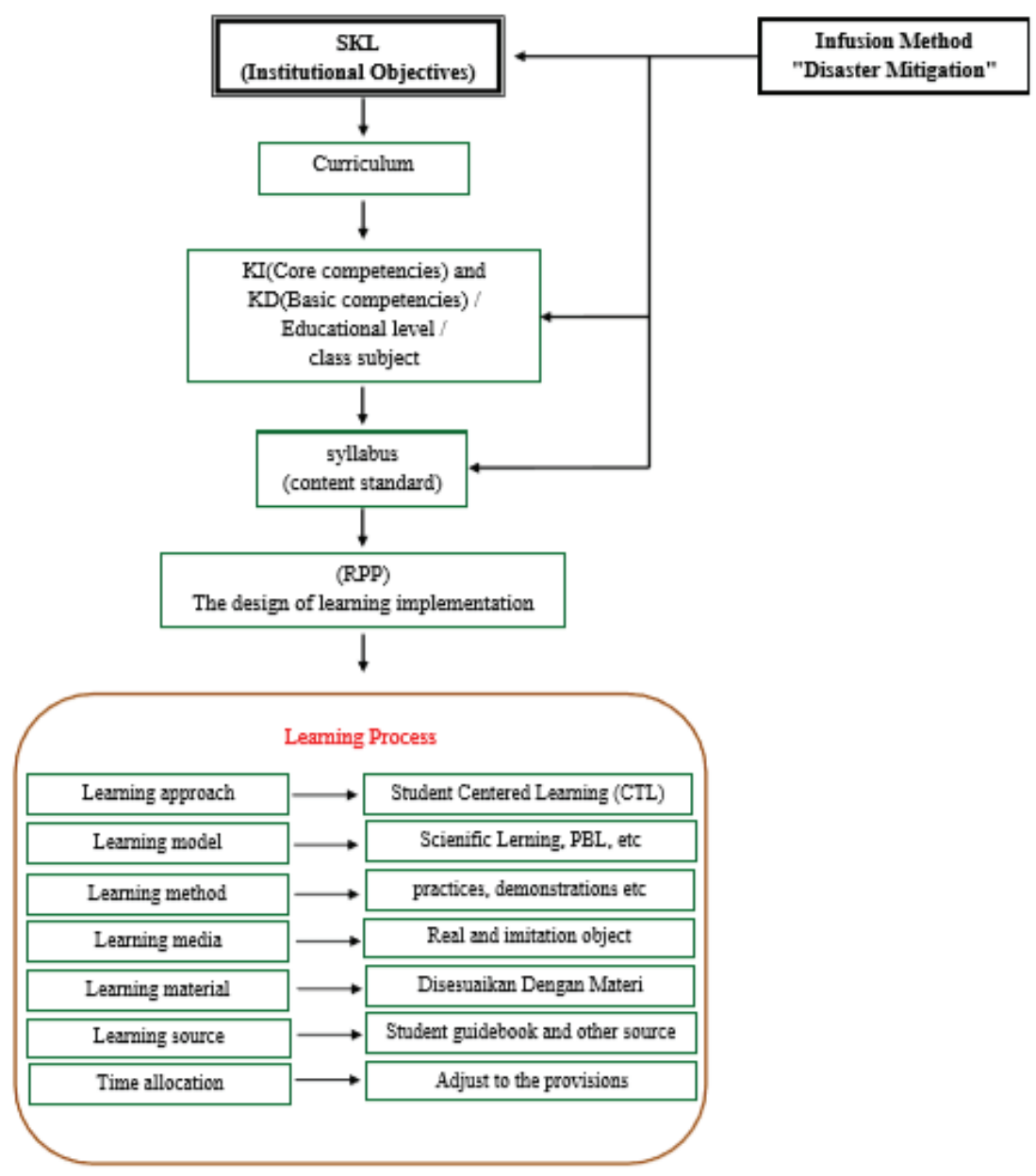

Figure 4. Concept of Learning Process (Intracuricular) 


\section{Training Process (Extracurricular)}

Disaster mitigation education emphasizes changes in students' actions, behavior and psychomotor. This is in line with the implementation of behavioristic theory which is the basis for the formation of disaster mitigation behaviors (Putrayasa, Ida, 2013). The disaster mitigation training program is a special program in providing disaster mitigation skills training. This training is targeted at elementary school students aged 6-12 years or at the operational stage(Matt Jarvis. 2011). In this stage, the child is mature enough to use logical thinking so that direct practice activities are very appropriate. The disaster mitigation training program unites and integrates information, perceptions and knowledge that has been learned in the learning process into practical activities (Sanjaya, 2010.)

The Disaster Mitigation Training Program is a product of the block method in the 2013 Curriculum. The base of developing disaster mitigation training programs is a needs analysis component, namely disaster mitigation skills. The design of the disaster mitigation training program is contained in the extracurricular syllabus. The syllabus is made by extracurricular developers such as coaches, teachers and other parties then get approval by the principal. The syllabus sets the design of the training program at each meeting.

The design of the implementation of the disaster mitigation training program used the training course concept so that the strategies and methods are practical. The model used in the training of disaster mitigation programs is ServiceL earning or Experiential Learning because it emphasizes the aspects of outside class learning. This model is appropriate in integrating disaster mitigation learning material in the classroom into outside class practice activities so that the formation of character and disaster mitigation skills is more optimal. The procedure of this training program is arranged into a training program guidebook that is used by students and for known by parent. The implementation of the disaster mitigation training program is carried out by special trainers from the BNPB of Indonesia, see in figuree 5

THE CONCEPT OF TRAINING PROCESS

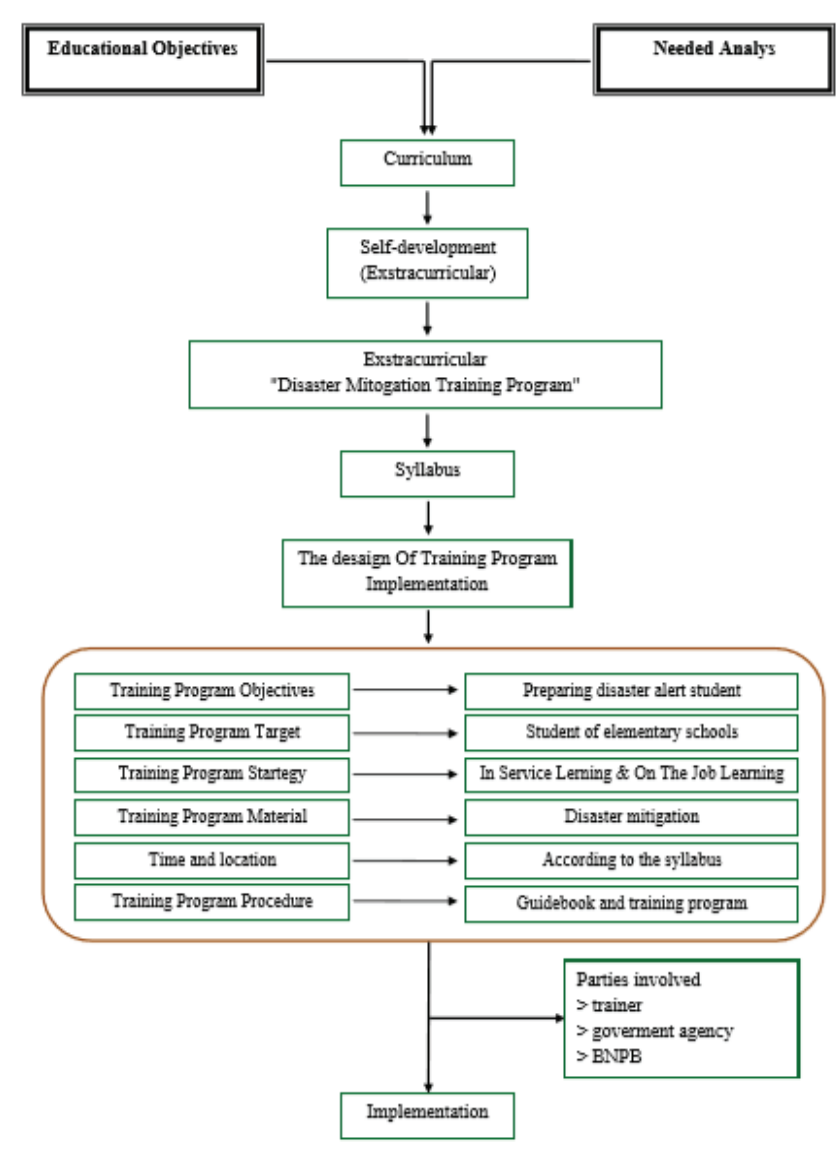

Figure 5. Concept of Training Process (Extracurricular) 


\section{Assessment Process (Evaluation)}

Evaluation is carried out on students, institutions, and educational programs in each education units (UU.No. 20 Tahun 2003). The process of assessing or evaluating disaster mitigation curriculum used a type of evaluation of results and processes with the main objectives among others: 1) to measure the level of disaster mitigation skills of students after the learning and training process, and 2) to assess the success of the intracurricular and extracurricular programs on the disaster mitigation curriculum (Redaksi Buletin Sanjaya, 2013). The evaluation of student learning outcomes is carried out by educators or teachers to monitor the process, progress, and improvement of student learning outcomes on an on going basis (UU.No. 20 Tahun 2003). The evaluation of process is an assessment that includes a directed, planned, systematic effort to examine the teaching and learning process that has been carried out (Dinata, et.al. 2014). The evaluation of process aims to measure the success of the program that has been designed.

The procedure for evaluating of results and processes begins with the evaluation planning step which includes designing main objective, indicators, targets, models till technical aspects of the evaluation. After that, the process of composing the instrument took the form of a question and draft that has previously been tested for validity and reliability(Arifin, 2012). The process of collecting data is the implementation step to obtain data using instruments that have been developed. The form of evaluation implementation depends on the type of instrument and evaluation model used.
The evaluation results is raw data that needs to be processed. The processing of data is the conversion of raw data into a data presentation that is easily understood and meaningful. Evaluation data in the form of qualitative data are processed and analyzed qualitatively, while quantitative data is processed and analyzed using descriptive and inferential statistical methods that have been processed with value conversion techniques (Dasimah 2015). The results of the evaluation process are reported to the parties related to the program and are used as material for improvement in the implementation of the learning and training process, see in Figure 6.

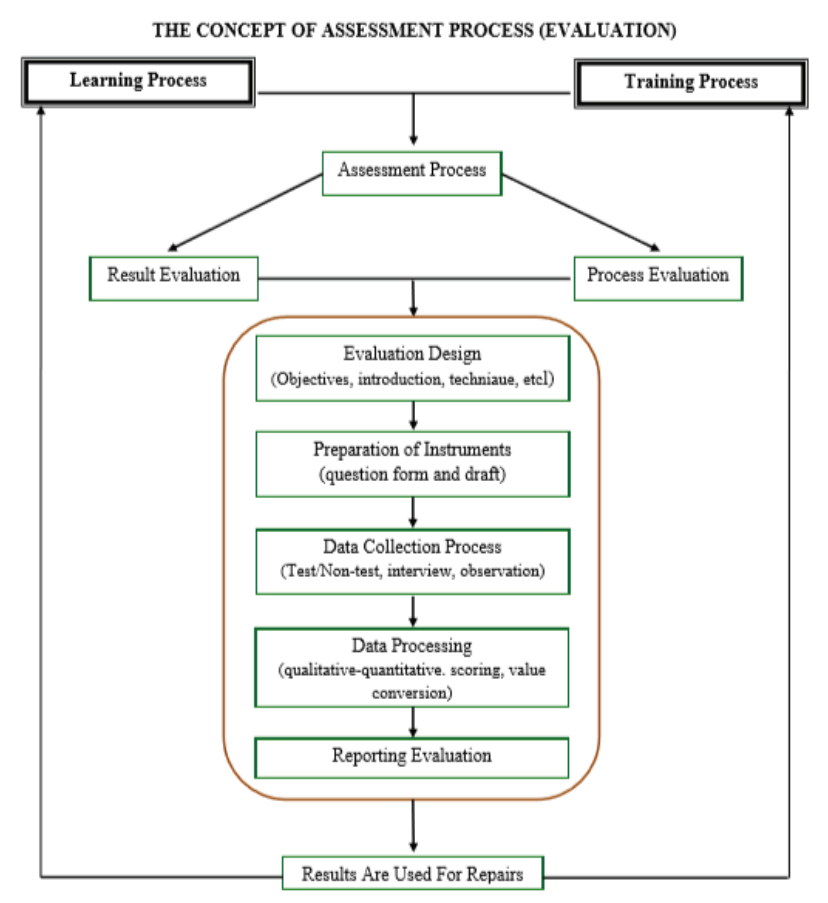

Figure 6. Concept of Assessment Process (Evaluation) 


\section{CONCLUSION}

Indonesia's region is in a disaster-prone area, so there must be an effort to minimize the impact of casualties at a young age. The effort taken is to create disaster mitigation learning programs into the curriculum. Through disaster mitigation curriculum can increase student knowledge about the level of awareness and perception of disaster risk and readiness in responding to disasters that occur. This research was carried out through four stages, namely 1) Concept of disaster mitigation curriculum, 2) Concept of learning process (Intracuricular) 3) Concept of training process, and 4) Concept of evaluation (evaluation) applied by infusion method and block method

Thus, we know that disaster mitigation curriculum is an effort to improve students' ability to respond about disasters). By increasing these capabilities, the impact of casualties at a young age can be minimized because of the right rescue efforts. Therefore, learning and disaster mitigation training in elementary schools is needed because young people have the ability to receive better material, so that the number of casualties can be minimized.

\section{REFERENCES}

Adiyoso, Wignyo and Hedehiko Kanegae. 2010. The Effect of Different Disasater Education Programs on Tsunami Praparedness Among Schoolchildren in Aceh, Indonesia. Disasater Mitigation of Cultural Heritage and Histories Cities. Vol 6, page 165-168

Apriana, Evi., 2012. Pengintegrasi Konsepbiokonservasi Dalam Pembelajaran Biologi Sebagai Upaya Menumbuhkan Literasi Dan Kesadaran Lingkungan Di Kalangan Siswa. Journal Serambi Ilmu, 13(1) $1-10$.
Arifin, Zaenal. (2012). Evaluasi Pembelajaran. Jakarta: Direktorat Jenderal Agama Islam Kementerian Agama

BNPB (National Board for Disaster Management).2014. Rencana Nasional Penanggulanagan Bencana 20152019.Jakarta, Page 10

BNPB (National Board for Disaster Management).2016. Risiko Bencana Indonesia.Jakarta, Page 14

Dasimah, Diana. N. 2015. Evaluasi Pembelajaran. Hal. 12-19. Pada tanggal 9 Juni 2019.

Dinata, I. W. B. Dan Ni Made Karismantari, I. 2014. Evaluasi Pendidikan: Evaluasi Proses Pendidikan dan Hasil Pendidikan dalam Praktik.https:// www.academia.edu/9591689/EVALUASI_ PENDIDIKAN_Evaluasi_Proses_Pendidikan_dan_ Hasil_Pendidikan_dalam_Praktik/. Diakses pada 9 Juni 2019.

Howard, J.2007. Universal Design For Learning: An Essential Concept For Teacher Education, Journal of Computing in Teacher Education, Page 113-118

Johnston, D.M, et.al. 1999. Volcanic Hazard Perception: Comparative Shift In Konwledge and Risk. Disaster Preventer \& Management, 8 (2) page 118-112

Judy, A.B.,\& Wood, D.(1993).Enviromental Education in the Schools. Creating a Program that Works Peace Corps Information Collection and Exchange

K.R.C, et, al. 2013.Mitigasi Bencana Banjir Rob di Jakarta Utara. Jurnal Teknik Pomits, C25-C30

Mardayati, Sofi. 2017. Dasi Sigap (Dalang Siswa Siap Siaga Bencana): Model Pendidikan Kebencanaan Sebagai Ekstrakurikuler Berbasis Kearifan Lokal di Daerah rawan Bencana di Indonesia. UNNES: Semarang)

Matt Jarvis. 2011. Teori-Teori Psikologi, Cet. X. Bandung: Nusa Media.

Miller, C. S. (2008). Meaningful work over the life course. (Dissertation, The faculty of fielding graduate university)

Nadler, D.A. \& Lawler III, Edward E. (1977), "Motivation: A Diagnostic Approach", Perspective 
on Behavior in Organizations, New York: Mc GrawHill: p 125-135

Okpokwasili P, N.2003.Tyler's Model For Curriculum Design In Social Studies. Port Harcourt: Rivers State University Of Science And Technology.

Pemerintah Indoneisa. 2003. Undang-Undang Nomor 20 Tahun 2003 tentang Sistem Pendidikan Nasional. Lembaran Negara Republik Indonesia Tahun 2003 Nomor 78, Tambahan Lembaran Negara Republik Indonesia Nomor 4301.

Pemerintah Indoneisa. 2007. Undang - Undang Republik Indonesia Nomor 24 Tahun 2007 Tentang Penanggulangan Bencana.. Lembaran Negara Republik Indonesia Tahun 2007 Nomor 66, Tambahan Lembaran Negara Republik Indonesia Nomor 4723

Pemerintah Indoneisa. 2016. Peraturan Menteri Pendidikan Dan Kebudayaan Republik Indonesia Nomor 20 Tahun 2016 Tentang Standar Kompetensi Lulusan Pendidikan Dasar Dan Menengah. Berita Negara Republik Indonesia Tahun 2016 Nomor 953.

Pemerintah Indonesia. 2006. Peraturan Menteri Pendidikan Nasional Republik Indonesia Nomor 22 Tahun 2006 Tentang Standar Isi Untuk Satuan Pendidikan Dasar Dan Menengah.

Putrayasa, Ida Bagus. 2013. Landasan Pembelajaran. Bali.Undiksha Press.
Redaksi Buletin Sańcaya. 2013. Service-Learning: Suatu Model Pembelajaran Alternatif. htttp://pip.unpar. ac.id/publikasi/buletin/sancaya-volume-02-nomor01-edisi-januari-2014-2/520-2/. Diakses pada 8 Juni 2019.

Rizaldy, David. 2018. Implementasi Pendidikan Mitigasi Bencana di Sekolah-Sekolah di IndonesiaSebagai Uoaya Pembentukan Karakter Siswa Siap Siaga. Prosiding PIT kr-5 Kebencanaan IABI page 479.

Sanjaya, Wina. 2010. Strategi Pembelajaran Berorietnasi Standar Proses Pendidikan, Cet. VII, Jakarta: Prenada Media Group

Shaw, R and Shiwaku, K. 2008. Proactive co-learning: A New paradigm in Disaster Education. Disasater Preventer \& Management. 17 (2) page 183-198

Suarmika, P. E., \& Utama, E. G. (2017). Pendidikan Mitigasi Bencana Di Sekolah Dasar (Sebuah Kajian Analisis Etnopedagogi). Jurnal Pendidikan Dasar Indonesia, 2(2), 18-24.

Subagio, W., Wiratma, G.L., \& Sudita, K. (2015). Pelatihan Mitigasi Bencana Alam Gempa Bumi Pada Siswa Sekolah Dasar Negeri 1 Pengastulan Kecamatan Seririt Kabupaten Buleleng Bali. Jurnal Pendidikan Indonesia, 4(1), 585-598.

William B. Werther, Jr. Dan Keith Davis, Human Resources and Personnel Management, 1996:282. 